\title{
PEMBERIAN BUAH PEPAYA MUDA (CARICA PAPAYA LINNAEUS) TERHADAP KECUKUPAN ASI PADA IBU POST PARTUM
}

\section{CARICA PAPAYA LINNAEUS ON ADEQUATE BREAST MILK IN POST PARTUM MOTHERS}

\author{
Bunga Tiara Carolin ${ }^{1}$, Jenny Anna Siauta², Irma Damayanti ${ }^{3}$ \\ Prodi Kebidanan, Fakultas IImu Kesehatan, Universitas Nasional, Jakarta Selatan, Indonesia \\ Correspondence Email: bunga.tiara@civitas.unas.ac.id
}

\begin{abstract}
ABSTRAK
ASI mengandung gizi tinggi yang sangat bermanfaat untuk kesehatan bayi, bahkan WHO merekomendasikan bayi untuk mendapatkan ASI eksklusif selama 6 bulan. Pencapaian ASI eksklusif di Indonesia belum mencapai angka yang diharapkan. Menurut Kemenkes RI pada (2018) cakupan pemberian ASI eksklusif hanya 36\% yang akan memberikan dampak negatif terhadap status kesehatan gizi, serta tingkat kecerdasan anak. Tujuan penelitian untuk mengetahui pengaruh pemberian buah papaya muda terhadap produksi ASI pada ibu post partum. Penelitian ini menggunakan quasy experiment dengan two group with pretest and postest design. Sampel berjumlah 30 ibu post partum yang melahirkan normal. Uji statistik yang digunakan adalah paired T-Test dan Independet T-Test. Rata-rata skor kecukupan ASI pada kelompok eksperimen sebelum diberikan buah pepaya muda adalah 5,93 dan sesudah adalah 14,60. Rata-rata kecukupan ASI pada kelompok kontrol sebelum adalah 6,60 dan sesudah adalah 7,86. Analisis bivariat menggunakan Independent ttest diperoleh $p$ value $=0,00$. Hal ini berarti ada perbedaan yang signifikan kecukupan ASI pada kelompok eksperimen dan kelompok kontrol. Buah pepaya muda terbukti menstimulasi produksi ASI. Oleh karena itu diharapkan bagi bidan unuk dapat memberikan penyuluhan tentang manfaat buah pepaya muda guna meningkatkan produksi ASI agar ibu memberikan ASI eksklusif.
\end{abstract}

Kata Kunci : kecukupan ASI; buah pepaya muda; ibu post partum

\begin{abstract}
Breast milk contains high nutrition which is very beneficial for the health babies, even WHO recommends babies to get exclusive breastfeeding for 6 months. The achievement of exclusive breastfeeding in Indonesia has not reached the expected number. According to the Indonesian Ministry of Health (2018) the coverage of exclusive breastfeeding is only $36 \%$ which will have a negative impact on the nutritional health status and the level of intelligence of children. The purpose of the study was to determine the effect of papaya fruit on breast milk production in post partum women. This study used a quasy experiment with two groups with pretest and posttest design. A sample of 30 postpartum women who gave birth normally. Data analysis had been done by paired T-Test and Independent T-Test. The average adequacy rate of postpartum women in the experimental group before being given raw papaya fruit was 5.93 and after 14.60. The mean postpartum breastfeeding adequacy rate in the control group before was 6.60 and after 7.86. Bivariate analysis using Independent t-test obtained $p$ value $=0.00$. There is a significant difference in the adequacy of breast milk in the experimental group and the control group. Papaya fruit is proven to stimulate breast milk production. Therefore, it is hoped that midwives can provide counseling about the benefits of young papaya fruit to increase milk production so that mothers provide exclusive breastfeeding
\end{abstract}

Key words : adequacy breat milk, young papaya fruit, postpartum women 


\section{PENDAHULUAN}

Pemberian ASI eksklusif selama 6 bulan dianjurkan oleh pedoman internasional yang didasarkan pada bukti ilmiah tentang manfaat ASI baik bagi bayi, ibu, keluarga maupun Negara (Rini \& Kumala 2016). ASI mengandung gizi tinggi yang sangat bermanfaat untuk kesehatan bayi, bahkan World Health Organization (WHO) merekomendasikan bayi untuk mendapatkan ASI eksklusif selama enam bulan. Pencapaian ASI eksklusif di Indonesia belum mencapai angka yang diharapkan (Paramita, 2016).

Data (WHO) tahun 2016 masih menunjukkan rata-rata angka pemberian ASI eksklusif di dunia baru berkisar 38\%. Di Indonesia meskipun sejumlah besar perempuan (96\%) menyusui anak mereka dalam kehidupan mereka, hanya $42 \%$ dari bayi yang berusia di bawah 6 bulan yang mendapatkan ASI eksklusif. Pada saat anakanak mendekati ulang tahunnya yang ke dua, hanya 55\% yang masih diberi ASI. Jika dibandingkan dengan target WHO yang mencapai 50\%, maka angka tersebut masihlah jauh dari target (Paramita, 2016).

Menurut Kementerian Kesehatan RI jumlah pemberian ASI eksklusif pada bayi 0-6 bulan tahun 2015 pemberian ASI eksklusif menurun menjadi 38,5 \% kemudian pada tahun 2018 cakupan pemberian ASI eksklusif hanya 36\% (Riskesdas, 2018).

Masih banyaknya ibu yang tidak memberikan ASI eksklusif akan memberikan dampak negatif terhadap status kesehatan gizi, serta tingkat kecerdasan anak. (Wiyani, 2018). Dampak tidak diberikan ASI eksklusif terhadap bayi adalah bertambahnya kerentanan terhadap penyakit baik ibu dan bayi. Dengan menyusui dapat mencegah $1 / 3$ kejadian infeksi saluran pernafasan atas, kejadian diare dapat turun 50\% dan penyakit usus parah pada bayi premature dapat berkurang kejaidannya sebanyak 58\%. Pada ibu, resiko kanker payudara juga dapat menurun 6-10\% (IDAI, 2013).

Menyusui sejak dini mempunyai dampak positif baik bagi ibu maupun bayinya. Bagi bayi, menyusui mempunyai peran penting untuk menunjang pertumbuhan, kesehatan dan kelangsungan hidup bayi arena ASI kaya dengan zat gizi dan antibody. Sedangkan bagi ibu, menyusui dapat mengurangi morbiditas dan mortalitas karena proses menyusi akan merangsang kontraksi uterus sehingga mengurangi perdarahan pasca melahirkan (Riskesdas, 2018)

Menurut Rini \& Kumala (2016) beberapa ibu kesulitan untuk memberikan ASI eksklusif pada bayinya. salah satu penyebab yang mendasari keadaan tersebut adalah karena produksi ASI yang berkurang atau menurun dan ibu jarang menyusui bayinya. Menurut Maryunani (2012) berbagai alasan ibu memiliki produksi ASI yang tidak adekuat adalah stimulasi payudara yang tidak adekuat, jarang menyusui, aktifitas berat, stress dan diet.

Menyusui dalam jangka panjang dapat meperpanjang jarak kelahiran karena masa amenorhoe lebih panjang. United Children's Fund (UNICEF) dan (WHO) membuat rekomendasi pada ibu untuk menyusui eksklusif selama 6 bulan kepada bayinya. Pemerintah Indonesia melalui Kementerian Kesehatan juga merekomendasikan para ibu untuk menyusui eksklusif selama 6 bulan kepada bayinya (Kemenkes, 2018).

Program ASI eksklusif pada Puskesmas sebenarnya dapat terjalankan dengan baik, ketika dukungan dan motivasi yang diberkan kepada sang ibu untuk memberikan ASI eksklusif kepada anak. Program Pemerintah Indonesia khususnya Departemen Kesehatan telah mengadopsi pemberian ASI eksklusif 6 bulan sesuai rekomendasi dari WHO dan UNICEF, sebagai salah satu program perbaikan gizi bayi atau balita. Sasaran program yang ingin dicapai dalam Indonesia Sehat 2015-2019 adalah sekurang-kurangnya $80 \%$ ibu menyusui memberikan ASI eksklusif (Damanik, Rahmawati et al. 2015).

Cara mengatasi masalah produksi ASI saat menyusui agar memudahkan ibu dan bayi adalah menghindari stress dan mengkonsumsi banyak makanan yang bisa meningkatkan produksi ASI (Istiqomah, 2015). Menurut dr. Yovita salah satu cara meningkatkan produksi ASI dengan 
mengkonsumsi ekstrak buah pepaya muda karena buah pepaya muda sudah lama dan melalui beberapa penelitian memang bermanfaat untuk meningkatkan produksi ASI. Dengan sesering mungkin bayi menyusu pada payudara ibu, maka produksi dan pengeluaran ASI akan semakin banyak. Oleh karena itu untuk menanggulangi permasalahan di atas perlu dilakukan upaya untuk meningkatkan penggunaan ASI dengan memberikan buah pepaya muda untuk ibu menyusui, sehingga membantu pengeluaran ASI secara lancar (Rini \& Kumala 2016).

Buah pepaya muda (Carica Papaya Linnaeus) mengandung laktagogum yang dapat membantu meningkatkan dan memperlancar pengeluaran ASI. Laktagogum memiliki efek dalam merangsang pengeluaran hormon oksitosin dan prolaktin seperti alkaloid, polifenol, steroid, flavonoid yang efektif dalam meningkatkan sekresi dan pengeluaran ASI (Muhartono, 2018).

Penelitian Suprihatin (2018) terhadap 20 orang ibu post partum dengan pemberian buah pepaya muda secara rutin 3 kali sehari sebanyak $600 \mathrm{mg}$ selama 7 hari. Menunjukkan bahwa terdapat perbedaan yang signifkan terhadap peningkatan produksi ASI pada ibu sebelum konsumsi buah pepaya muda. Menurut penelitian Diah (2016) terhadap 44 ibu post partum primipara yang dibagi menjadi kelompok intervensi diberikan kapsul ekstrak buah pepaya muda selama 14 hari dengan dosis $150 \mathrm{mg}$ dan kelompok kontrol diberikan plasebo. Hasil penelitian menunjukkan bahwa indikator kecukupan ASI mengalami peningkatan pada kelompok intervensi. Berat badan bayi meningkat sampai 327,3 gram, frekuensi BAK bayi meningkat 2 kali, frekuensi BAB meningkat 2 kali, frekuensi tidur meningkat 2,73 jam, frekuensi menyusui meningkat 4 kali dibandingkan kelompok kontrol. Penelitian ini berarti ektrak buah pepaya muda memiliki potensi sebagai bahan alternatif untuk kecukupan ASI ibu.

Berdasarkan hasil studi pendahuluan yang dilakukan di PMB Rika Jambe Tangerang, peneliti menemukan 38 ibu yang memiliki bayi berusia dibawah 6 bulan diantaranya 8 orang yang memberikan ASI eksklusif $(21,1 \%)$ dan 30 orang yang tidak memberikan ASI eksklusif $(78,9 \%)$ dengan alasan karena produksi ASI berkurang, dan sebagian ibu bekerja. Berdasarkan latar belakang diatas maka peneliti penting untuk melakukan penelitian dengan judul "Pengaruh Pemberian Buah Pepaya Muda (Carica Papaya Linnaeus) Terhadap Kecukupan ASI Pada Ibu Post Partum" dengan Tujuan penelitian untuk mengetahui pengaruh pemberian buah papaya muda terhadap produksi ASI pada ibu post partum.

\section{METODE}

Penelitian ini menggunakan jenis penelitian quasy experiment dengan rancangan two group pretest-posttest design. Populasi dalam penelitian ini adalah adalah seluruh ibu post partum pada periode Maret - Mei Tahun 2020 di Praktik Mandiri Bidan Rika Jambe Tangerang yang berjumlah 106 orang.. Teknik pengambilan sampel menggunakan purposive sampling. Kriteria inklusi yaitu ibu post partum dengan normal; ibu post partum dengan menyusui 3 atau 4 hari dengan kecukupan ASI sedikit atau tidak cukup; Bentuk payudara normal atau tidak ada kelainan; Bersedia untuk diteliti. sedangkan kriteria eksklusinya yaitu bayi yang memiliki gangguan kesehatan; ibu yang memiliki penyakit menular. Alat ukur dalam penelitian ini menggunakan lembar observasi untuk mengukur kecukupan ASI dan lembar kegiatan untuk mencatat jadwal pemberian buah pepaya muda setiap hari selama 7 hari. Bahan dalam penelitian ini Sebanyak 600 gram dalam bentuk buah pepaya diberikan 3 kali sehari selama 7 hari. Berdasarkan hasil uji normalitas juga didapatkan bahwa data berdistribusi normal sehingga analisis data menggunakan paired $t$ test dan Independen t test.

\section{HASIL}

Tabel 1 menunjukkan pada kelompok eksperimen rata-rata sebelum diberikan buah pepaya muda 5,93 dan sesudah diberikan buah pepaya muda adalah 14,60. Hasil ini 
menunjukkan adanya peningkatan produksi ASI sesudah diberikan buah pepaya muda. Sedangkan pada kelompok kontrol pretest didapatkan rata-rata kecukupan ASI yaitu 6,60 dan sesudah dengan rata-rata produksi ASI yaitu 7,86. Hal ini menunjukkan ada peningkatan rata-rata kecukupan ASI pada kelompok kontrol, namun tidak signifikan.

Tabel 1.

Perbedaan kecukupan ASI Sebelum Dan Sesudah Diberikan Buah Pepaya Muda Pada Kelompok Eksperimen dan Kontrol

\begin{tabular}{cccc}
\hline \multicolumn{4}{c}{ Kelompok Eksperimen } \\
\hline Kecukupan ASI & $\mathbf{N}$ & Mean \pm SD & p-value \\
\hline sebelum & 15 & $\begin{array}{c}5,93 \pm 2,46 \\
14,60 \pm 2,58\end{array}$ & 0,000 \\
sesudah & 15 & 0,000 \\
\hline \multicolumn{4}{c}{ Kelompok Kontrol } \\
\hline sebelum & 15 & $\begin{array}{l}6,60 \pm 1,80 \\
7,86 \pm 2,35\end{array}$ & 0,137 \\
\hline
\end{tabular}

Ada perbedaan pada kecukupan ASI ibu pada kelompok kontrol dan eksperimen, nilai mean pada kelompok eksperimen adalah 14,60 dan kelompok kontrol 7,86 , nilai $p$ value $=0,001$

Tabel 2

Perbedaan kecukupan ASI Ibu Post Partum Antar Kelompok Posttest Eksperimen dan Kontrol

\begin{tabular}{cccc}
\hline \multicolumn{4}{c}{ Kelompok Eksperimen } \\
\hline Kecukupan ASI & $\mathbf{N}$ & Mean \pm SD & p-value \\
\hline Eksperimen & \multirow{2}{*}{15} & $\begin{array}{c}14,60 \pm 2,58 \\
7,86 \pm 2,35\end{array}$ & 0,001 \\
\hline Kontrol & &
\end{tabular}

\section{PEMBAHASAN \\ Kecukupan ASI Sebelum dan Sesudah Pada Kelompok Eksperimen}

Hasil penelitian menunjukkan pada kelompok eksperimen rata-rata sebelum diberikan buah pepaya muda 5,93 dan sesudah diberikan buah pepaya muda adalah 14,60 . Hasil ini menunjukkan adanya peningkatan produksi ASI sesudah diberikan buah pepaya muda. Berdasarkan hasil penelitian dapat diketahui bahwa kelompok eksperimen pretest termasuk dalam kategori tidak cukup dan postest termasuk dalam kategori lebih dari cukup.
Laktagogum merupakan obat yang dapat meningkatkan atau memperlancar pengeluaran air susu. Laktagogum sintetis tidak banyak dikenal dan relatif mahal. Hal ini menyebabkan perlu dicarinya obat laktagogum alternatif. Upaya dalam peningkatan produksi ASI bisa dilakukan dengan cara melakukan perawatan payudara sejak dini dan rutin, memperbaiki teknik menyusui, atau dengan mengkonsumsi makanan yang dapat mempengaruhi kecukupan ASI Istikhomah, dkk (2015). Pada penelitian yang dilakukan oleh Siagian dan Herlina (2020) rata-rata volume produksi ASI sebelum konsumsi pepaya hijau yaitu 67,67 sedangkan setelahnya meningkat menjadi 74,63 .

Hasil uji statistik menggunakan didapatkan nilai $p$ value $=0,000$, hal ini berarti $\mathrm{Ha}$ diterima dan ho ditolak sehingga ada pengaruh pemberian buah pepaya muda terhadap produksi ASI pada ibu post partum.

Penelitian ini sejalan dengan penelitian Istiqomah, dkk (2015) tentang pengaruh buah pepaya muda terhadap kelancaran produksi ASI pada ibu menyusui. Membuktikan bahwa dari hasil 20 orang responden yang diberikan buah pepaya muda mengalami peningkatan produksi ASI dilihat dari frekuensi menyusui bayi. Penelitian ini sejalan dengan penelitian Efek Ekstrak Air Buah Pepaya Muda (Carica Pepeaya L) terhadap Gambaran Histologi Kelenjer Mamma Mancit Laktasi pada Tahun 2011 didapatkan hasil penelitian, diameter kelenjer mamma laktasi rata-rata induk mancit kelompok ekstrak air buah pepaya muda lebih besar dibandingkan dengan kelompok kontrol negatif (Kharisma dkk, 2011).

Pada temuan hasil di peneliti, ditemukan adanya peningkatan kecukupan ASI sesudah diberikan buah pepaya muda dikarenakan buah pepaya merupakan jenis tanaman yang mengandung laktagogum memiliki potensi dalam menstimulasi hormon oksitoksin dan prolaktin seperti alkaloid, polifenol, steroid, flavonoid dan substansi lainnya paling efektif dalam meningkatkan dan memperlancar produksi ASI. Hasil di lapangan didapatkan pengaruh buah pepaya muda terhadap kecukupan ASI karena dengan dapat menstimulasi hormon pelancar ASI 


\section{Kecukupan ASI pada Ibu Post Partum Sebelum dan Sesudah Pada Kelompok Kontrol}

Hasil penelitian menunjukkan bahwa pada kelompok kontrol pretest didapatkan rata-rata kecukupan ASI yaitu 6,60 dan sesudah dengan rata-rata produksi ASI yaitu 7,86. Hal ini menunjukkan ada peningkatan rata-rata kecukupan ASI pada kelompok kontrol, namun tidak signifikan. Hasil ini menunjukkan bahwa pada kelompok kontrol pretest maupun postest kecukupan ASI ibu termasuk dalam kategori tidak cukup. Hasil uji statistik juga menunjukkan nilai $p$ value $=0,137$ hal ini berarti ha ditolak dan Ho diterima sehingga tidak ada pengaruh produksi ASI ibu post partum pada kelompok kontrol.

Menurut Rini \& Kumala (2016) beberapa ibu kesulitan untuk memberikan ASI eksklusif pada bayinya. salah satu penyebab yang mendasari keadaan tersebut adalah karena produksi ASI yang berkurang atau menurun dan ibu jarang menyusui bayinya.

Menurut Maryunani (2012) berbagai alasan ibu memiliki produksi ASI yang tidak adekuat adalah stimulasi payudara yang tidak adekuat, jarang menyusui, aktifitas berat, stress dan diet. Pada penelitian Sebayang (2020), terdapat perbandingan yang cukup bermakna antara kelompok kontrol dan intervensi, dimana kelompok intervensi 81,3\% memperoleh ASI yang cukup, sedangkan pada kelompok kontrol hanya $31,3 \%$ responden dengan kategori ASI cukup.

Pada penelitian kali ini kelompok kontrol ada peningkatan kecukupan ASI meskipun tidak signifikan dikarenakan faktor yang mempengaruhi kecukupan ASI adalah kejiwaan ibu, pengetahuan ibu dan keadaan bayi yang sehat.

\section{Pengaruh Kecukupan ASI pada ibu Post Partum}

Berdasarkan penelitian menunjukkan nilai mean pada kelompok eksperimen adalah 14,60 dan kelompok kontrol 7,86 , nilai $p$ value $=0,001$ hal ini berarti ada perbedaan kecukupan ASI pada kelompok eksperimen dan kelompok kontrol. Penelitian ini didukung oleh penelitian Istiqomah, dkk (2015) didapatkan nilai $p=0,005$ ( $p$ artinya ada pengaruh pemberian buah pepaya muda terhadap kelancaran produksi ASI dan pada penelitian efek ekstrak air buah pepaya muda (Carica Papaya L) terhadap gambaran histologi kelenjer mamma mancit laktasi pada tahun 2011 didapatkan hasil penelitian, diameter kelenjer mamma laktasi rata-rata induk mancit kelompok ekstrak air buah pepaya muda lebih besar dibandingkan dengan kelompok kontrol negatif.

Buah pepaya muda merupakan jenis tanaman yang mengandung laktagogum memiliki potensi dalam menstimulasi hormon oksitosin dan prolaktin seperti alkolid, polifenol, steroid flavonoid dan substansi lainnya paling efektif dalam meningkatkan dan memperlancar produksi ASI. Reflek prolaktin secara hormonal untuk memproduksi ASI, waktu bayi menghisap puting payudara ibu, terjadi rangsangan neorohormonal pada putting susu dan areola ibu. Rangsangan ini diteruskan ke hipofisis melalui nervos vagus, kemudian ke lobus anterior. Dari lobus ini akan mengeluarkan hormon prolaktin, masuk ke peredaran darah dan sampai pada kelenjerkelenjer pembuat ASI. Kelenjer ini akan merangsang untuk menghasilkan ASI (Istiqomah, dkk 2015).

Peningkatan produksi ASI dipengaruhi oleh adanya polifenol dan steroid yang mempengaruhi reflek prolaktin untuk merangsang alveolus yang bekerja aktif dalam pembentukan ASI. Peningkatan produksi ASI juga dirangsang oleh hormon oksitosin, peningkatan hormon oksitosin dipengaruhi oleh polifenol yang ada pada buah pepaya muda yang akan membuat ASI mengalir lebih deras dibandingkan dengan sebelum mengkonsumsi buah pepaya muda.

Oksitosin merupakan hormon yang berperan untuk mendorong sekresi air susu (milk let down). Peran oksitosin pada kelenjer susu adalah mendorong kontraksi sel-sel miopitel yang mengelilingi alveolus akan terdorong keluar menuju saluran susu, sehingga alveolus menjadi kosong dan 
memacu untuk sintesis air susu berikutnya (Istiqomah, dkk 2015).

Buah pepaya muda merupakan jenis tanaman yang mengandung laktagogum memiliki potensi dalam menstimulasi hormon oksitoksin dan prolaktin seperti alkaloid, polifenol, steroid, flavonoid dan substansi lainnya paling efektif dalam meningkatkan dan memperlancar produksi ASI. Reflek prolaktin secara hormonal untuk memproduksi ASI, waktu bayi menghisap puting payudara ibu, terjadi rangsangan neorohormonal pada puting susu dan areola ibu. Rangsangan ini diteruskan ke hipofisis melalui nervos vagus, kemudian ke lobus anterior. Dari lobus ini akan mengeluarkan hormon prolaktin, masuk ke peredaran darah dan sampai pada kelenjarkelenjar pembuat ASI. Kelenjar ini akan terangsang untuk menghasilkan ASI (Murtiana, 2011).

Pemanfaatan buah pepaya muda pada masyarakat sudah banyak ditemui, seperti baik untuk kesehatan mata, baik untuk pencernaan, digunakan untuk membuat sayur karena kandungan protein dan vitamin, serta dimakan untuk memperlancar dan memperbanyak produksi ASI. Pengolahan buah pepaya muda pada masyarakat biasa dilakukan dengan cara direbus, diurap, dikukus dan dioseng-oseng. Buah pepaya menjadi bahan makanan yang memiliki banyak manfaat dan mudah didapatkan oleh masyarakat karena bisa dengan mudah ditanam di pekarangan rumah. Hasil penelitian sejalan dengan teori Lingga dalam Murtiana (2011), yang menyatakan bahwa buah pepaya memiliki beberapa senyawa yang dapat meningkatkan produksi dan kualitas ASI. Peningkatan produksi ASI dipengaruhi oleh adanya polifenol dan steroid yang mempengaruhi reflek prolaktin untuk merangsang alveoli yang bekerja aktif dalam pembentukan ASI. Hasil penelitian ini juga menyatakan bahwa peningkatan produksi ASI juga dirangsang oleh hormon oksitosin.

Peningkatan hormon oksitosin dipengaruhi oleh polifenol yang ada pada buah pepaya muda yang akan membuat ASI mengalir lebih deras dibandingkan dengan sebelum mengkonsumsi buah pepaya. Oksitosin merupakan hormon yang berperan untuk mendorong sekresi air susu (milk let down). Peran oksitosin pada kelenjar susu adalah mendorong kontraksi sel-sel miopitel yang mengelilingi alveolus dari kelenjar susu, sehingga dengan berkontraksinya sel-sel miopitel isi dari alveolus akan terdorong keluar menuju saluran susu, sehingga alveolus menjadi kosong dan memacu untuk sintesis air susu berikutnya.

Korelasi ini sesuai dengan hasil penelitian yang telah dilakukan oleh penelitian Agil (1987) dalam Murtiana (2011), menyatakan bahwa tanaman yang berkhasiat terhadap peningkatan sekresi air susu (laktogogum) mempunyai kemungkinan: (1) mengandung bahan aktif yang bekerja seperti Prolactin Releasing Hormon (PRH), (2) mengandung bahan aktif senyawa steroid, (3) mengandung bahan aktif yang berkhasiat seperti prolaktin dan (4) mengandung bahan aktif yang berkhasiat seperti oksitosin.

Menurut asumsi peneliti pada kelompok kontrol terjadi peningkatan kadar hemoglobin tetapi tidak signifikan dikarenakan pada kelompok kontrol tidak diberikan buah pepaya muda hanya mengkonsumsi makanan seharihari, sedangkan untuk kelompok eksperimen diberikan buah peapaya muda sehingga stimulasi hormon dapat meningkatkan produksi ASI. Kecukupan ASI itu terjadi bukan hanya karena adanya intervensi namun kecukupan ASI dapat terjadi pada hari ke 3 post partum dan juga adanya hisapan dari bayi.

\section{KESIMPULAN}

Berdasarkan hasil penelitian dan pembahasan maka dapat disimpulkan sebagai berikut ratarata kecukupan ASI sebelum diberikan buah pepaya muda adalah 5,93 termasuk kategori tidak cukup dan sesudah diberikan buah pepaya muda adalah 14,60 termasuk kategori lebih dari cukup. Rata-rata kecukupan ASI pada ibu post partum pada kelompok kontrol sebelum intervensi adalah 6,60 dalam kategori tidak cukup dan sesudah intervensi adalah 7,86 termasuk dalam kategori cukup. Terdapat pengaruh yang signifikan kecukupan ASI pada ibu post partum yang diberikan buah pepaya muda dengan $p$ value $=0,001$. Diharapkan 
bagi bidan unuk dapat memberikan penyuluhan tentang manfaat buah pepaya muda guna meningkatkan produksi ASI agar ibu memberikan ASI eksklusif.

\section{REFERENSI}

Damanik, R. Y., Rahmawati, W., \& Dini, S. (2015). Hambatan Kinerja Konselor Menyusui dalam Meningkatkan Cakupan Pemberian ASI Eksklusif di Kota Kupang. Indonesian Journal of Human Nutrition, 2(1), 1-10.

Indonesia, I. D. A. (2013). Indonesian Pediatric Society. Nilai Nutrisi Air Susu Ibu.

Istiqomah, S. B. T., Wulanadari, D. T., \& Azizah, N. (2015). Pengaruh buah pepaya terhadap kelancaran produksi ASI pada ibu menyusui di desa Wonokerto wilayah puskesmas Peterongan Jombang tahun 2014. Eduhealth, 5(2).

Kharisma, Y., Ariyoga, A., \& Sastramihardja, H. S. (2011). Efek ekstrak air buah pepaya (Carica papaya L.) muda terhadap gambaran histologi kelenjar mamma mencit laktasi. Majalah Kedokteran Bandung, 43(4), 160-165.

Maryunani, A. (2012). Inisiasi menyusui dini, ASI eksklusif dan manajemen laktasi. Jakarta: Trans Info Media.

Muhartono, M., Graharti, R., \& Gumandang, H. P. (2018). Pengaruh Pemberian Buah Pepaya (Carica Papaya L.) terhadap Kelancaran Produksi Air Susu Ibu (ASI) pada Ibu Menyusui. Jurnal Medula, 8(1), 39-43.
Murtiana, T. (2011). Pengaruh Konsumsi Buah Pepaya Dengan Peningkatan Produksi ASI Pada Ibu Menyusui Di Wilayah Puskesmas Sawah Lebar Kota Bengkulu Tahun 2011. Jurusan Kebidanan Poiteknik Kesehatan Bengkulu, Bengkulu

Paramita, I. (2016). Hubungan Antara Jenis Pekerjaan Ibu Dengan Keberhasilan Pemberian ASI Eksklusif 6 Bulan Pertama di Puskesmas Rangkah Surabaya (Doctoral dissertation, Universitas Airlangga).

Rini, S., \& Kumala, F. (2017). Panduan Asuhan Nifas dan Evidence Based Practice. Deepublish.

Riskesdas, L. (2018). Badan Penelitian dan Pengembangan Kesehatan. Jakarta: Kementerian Kesehatan RI.

Sebayang, W. B. (2020). Pengaruh Konsumsi Buah Pepaya (Carica Papaya L.) terhadap Peningkatan Produksi Asi. Jurnal IImiah Kebidanan Imelda, 6(1), 13-16.

Siagian, D. S., \& Herlina, S. (2020). Konsumsi Pepaya Hijau Terhadap Peningkatan Produksi Asi. Jurnal Endurance: Kajian IImiah Problema Kesehatan, 5(3), 514-521.

Suprihatin, D. S. (2018). Perbedaan Produksi Asi Dalam Pemberian Olahan Buah Pepaya Pada Ibu Postpartum Di Bpm Maria Kota Bandar Lampung Tahun 2018. Jurnal Kesehatan Dan Kebidanan (Journal Of Health And Midwifery), 7(2), 1-8. 